\title{
KEBIJAKAN PENGELOLAAN DANA PENDIDIKAN \\ TINGKAT SEKOLAH DALAM \\ KONTEKS OTONOMI DAERAH
}

\author{
Ujang Cepi Barlian \\ Pascasarjana IAINU Kebumen \\ e-mail: ujangcepibarlian@gmil.com
}

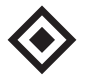

\begin{abstract}
Abstrak
Kesadaran tentang pentingnya pendidikan yang bermutu dapat memberikan harapan dan kemungkinan yang lebih baik di masa mendatang. Hal ini telah mendorong berbagai upaya dan perhatian seluruh lapisan masyarakat untuk bisa meningkatkan kualitas pendidikan. Sekolah sebagai institusi (lembaga) pendidikan, merupakan wadah tempat proses pendidikan dilakukan, memiliki sistem yang kompleks dan dinamis. Dalam kegiatannya, sekolah adalah tempat yang bukan hanya sekadar tempat berkumpul guru dan murid, melainkan berada dalam satu tatanan sistem yang rumit dan saling berkaitan. Oleh karena itu, sekolah dipandang sebagai suatu organisasi yang membutuhkan pengelolaan, termasuk didalamnya pengelolaan dana. Otonomi daerah dan desentralisasi pendidikan menuntut pemerataan pelayanan pendidikan yang berkeadilan, antara lain mengenai pengelolaan dana pendidikan yang adil dan transparan. Ini perlu ditekankan dan diprioritaskan, karena dana merupakan salah satu faktor penentu kualitas pendidikan yang secara langsung berkaitan dengan tujuan pendidikan.
\end{abstract}

Kata Kunci: Pengelolaan Dana, Pendidikan, Otonomi Daerah

\section{A. Latar Belakang Masalah}

Pembangunan pendidikan dan pembangunan ekonomi sama pentingnya, karena ekonomi akan sulit digerakkan jika sumber daya manusia (SDM) 
tidak mempunyai kemampuan untuk menggerakkan roda ekonomi. Untuk mendapatkan sumber daya manusia (SDM) yang berkemampuan dan berketerampilan, tentu sejak dini harus dipersiapkan. Lembaga yang paling mungkin menyiapkan sumber daya manusia (SDM) yang handal dan bermoral adalah pendidikan pada semua jenis dan jenjang. ${ }^{1}$

Negara-negara maju seperti Jepang, Korea, dan sebagainya tidak memiliki sumber daya alam yang memadai, tetapi mereka memiliki sumber daya manusia (SDM) yang handal.Oleh karena itu, mereka dapat menikmati kehidupan yang layak karena daya dukung ekonomi negaranya cukup untuk memenuhi kebutuhan rakyatnya. Bagi Negara Indonesia, modal sumber daya alam sudah terbentang secara luas, tinggal meningkatkan kualitas sumber daya manusia (SDM-nya).

Kewenangan yang terlalu terpusat di masa lalu telah menjadi bagian dari sebab kualitas dan kemandirian bangsa yang rentan. Kesuksesan yang dicapai ternyata bagaikan fatamorgana karena kenyataannya Negara Indonesia mengalami krisis yang berkepanjangan.Maka, di era sekarang ini kewenangan yang terpusat secara lambat laun telah dilimpahkan pada pemerintahan di bawahnya (otonomi daerah) sebagai upaya pemberdayaan daerah secara optimal.

Kebijakan pemberian otonomi daerah dan desentralisasi yang luas, nyata, dan bertanggung jawab kepada daerah merupakan langkah strategis dalam dua hal. Pertama, otonomi daerah dan desentralisasi merupakan jawaban atas permasalahan lokal bangsa berupa ancaman disintegrasi bangsa, kemiskinan, ketidakmerataan pembangunan, rendahnya kualitas hidup masyarakat, dan masalah pembangunan sumber daya manusia. Kedua, otonomi daerah dan desentralisasi merupakan langkah strategis bangsa Indonesia untuk menyongsong era globalisasi ekonomi dengan memperkuat basis perekonomian daerah. $^{2}$

Upaya peningkatan kualitas pendidikan terus-menerus dilakukan, baik secara konvensional maupun inovatif, dan lebih terfokus lagi setelah

1 Maman Rusmana, Formasi: Jurnal Kajian Manajemen Pendidikan, (Bandung: PPs UPI, 2000), hlm. 36.

2 Mardiasmo, Otonomi \& Manajemen Keuangan Daerah, (Yogyakarta: Andi, 2002), hlm. 96. 
diamanatkan bahwa tujuan pendidikan nasional adalah untuk meningkatkan mutu pendidikan pada setiap jenis dan jenjang pendidikan. Diantara upaya peningkatan kualitas pendidikan antara lain dikeluarkannya Undang-Undang Nomor 22 dan 25 tahun 1999 tentang Otonomi Daerah, yang secara langsung berpengaruh terhadap perencanaan, pelaksanaan, dan evaluasi pendidikan. Jika sebelumnya pengelolaan pendidikan merupakan wewenang pusat, maka dengan berlakunya undang-undang tersebut kewenangannya bergeser pada pemerintah daerah dan sekolah itu sendiri.

Pengelolaan pendidikan yang efektif dan efisien perlu ditunjang oleh dana yang memadai. Oleh karena itu, dalam penyelenggaraan pendidikan, sumber dana merupakan potensi yang sangat menentukan dan merupakaan bagian yang tak terpisahkan dalam kajian pengelolaan pendidikan. Hal tersebut lebih terasa lagi dalam implementasi otonomi daerah dan desentralisasi pendidikan, yang menuntut kemampuan sekolah untuk merencanakan, melaksanakan, dan mengevaluasi serta mempertanggungjawabkan pengelolaan dana secara transparan.

Pentingnya dana dalam penyelenggaraan pendidikan menuntut perencanaan yang tepat dan transparan. Sehubungan dengan itu, masalah yang akan dijadikan bahan kajian dalam tulisan ini adalah Bagaimanakah kebijakan pengelolaan dana pendidikan tingkat sekolah dalam konteks otonomi daerah?

\section{B. Pendanaan Pendidikan}

Pentingnya pendanaan pendidikan bukan hanya untuk kesejahteraan guru semata,melainkan lebih dari itu, karena komponen pembiayaan paling tidak menyangkut sarana dan prasarana, kebutuhan guru, kebutuhan siswa, kebutuhan kantor pendidikan, tenaga ahli pendidikan, dan lainnya sebagai daya dukung peningkatan kualitas pendidikan. ${ }^{3}$ Pemerintah Indonesia bukan hanya mengontrol pendidikan di berbagai pulau, melainkan pula merupakan sumber dana utama untuk seluruh jenis persekolahan.

Pendidikan merupakan sumber kunci outcome proses pembangunan. Para pengambil kebijakan pendidikan perlu menggambarkan sebuah snapshot

3 Maman Rusmana, Formasi: Jurnal Kajian Manajemen Pendidikan, (Bandung: PPs UPI, 2000), hlm. 39. 
mengenai pemakaian dana pendidikan selama satu tahun (1995-1996) dengan data yang bersumber dari pemerintah, persekolahan, dan keluarga-keluarga di berbagai tingkat dan jenis persekolahan. Data mengenai pembiayaan dipresentasikan dalam tiga hal.Pertama, keseluruhan biaya pendidikan di Indonesia yang terdiri atas: (a) dana pemerintah di luar anggaran pemerintah pusat, yaitu anggaran rutin dan anggaran pembangunan; (b) pembayaran atau kontribusi dari siswa/keluarga; (c) sumber-sumber pembiayaan lain yang tidak selalu disediakan oleh sekolah seperti biaya transportasi, seragam, buku-buku penunjang, dan lain sebagainya.

Kedua, biaya sistem pendidikan, yaitu suatu kombinasi dana-dana pemerintah dan ketersediannya untuk memenuhi kontribusi bagi pengeluaran sekolah yang bersumber dari pemerintah pusat dan daerah, masyarakat, keluarga siswa atau sumber-sumber lain. Ketiga, dana yang dibelanjakan untuk proses pengajaran, termasuk pengeluaran sekolah untuk gaji, barang-barang lain, dan berbagai pelayanan di SD, SLTP, dan SMA.

Perlunya dana pendidikan, baik pada jalur sekolah maupun luar sekolah terutama untuk menunjang penyediaan sarana dan prasarana, seperti tanah, bangunan, laboratorium, perpustakaan, media belajar, operasi pembelajaran, serta pelayanan administratif. Dana pendidikan tidak selalu identik dengan uang (red cost), tetapi mencakup semua pengorbanan yang diberikan dalam rangka mencapai tujuan penyelenggaraan pendidikan.

\section{Klasifikasi Dana Pendidikan}

Pendidikan mempunyai nilai monetary,baik langsung maupun tidak langsung (direct and indirect cost), sehingga sekolah tidak bebas dari dana. Keseluruhan dana pendidikan yang digunakan peserta didik untuk mengikuti kegiatan pembelajaran di sekolah selama satu periode anggaran disebut total student education cost. Thomas (1971) mengklasifikasikan dana pendidikan ke dalam dan langsung dan dan tidak langsung, dana masyarakat dan pribadi, monetary and non monetary cost. Hal tersebut dijelaskan sebagai berikut.

1. Dana Langsung dan Dana Tidak Langsung

Dana langsung (direct cost) adalah dana yang langsung digunakan untuk operasional sekolah, yang mencakup dana pembangunan (capital cost) dan 
dana rutin (recurrent cost).Sementara dana tidak langsung (indirect cost) adalah dana yang menunjang peserta didik untuk dapat hadir di sekolah, yang mencakup biaya hidup, transportasi, dan dana lainnya. Dana tidak langsung sulit dihitung karena tidak ada catatan resmi sehingga dana ini tidak turut dihitung, dalam perencanaan oleh para administrator, perencana, atau pembuat keputusan.

Dana pembangunan (capital cost) adalah dana yang digunakan untuk pembelian tanah pembangunan ruang kelas, perpustakaan, dan lapangan olahraga, dana kontruksi bangunan, pengadaan perlengkapaan mebelair, dana penggantian dan perbaikan. Penetuan dana pembanguan digunakan konsep capital cost per student place, yang terdiri atas tiga kelompok, yaitu untuk peserta didik di sekolah, asrama peserta didik, dan tempat tinggal guru.

Dana rutin (recurrent cost) adalah dana yang digunakan untuk membiayai kegiatan operasional pendidikan selama satu tahun anggaran. Dana rutin digunakan untuk menunjang pelaksanaan program pembelajaran, pembayaran gaji guru dan personel sekolah, administrasi kantor, pemeliharaan dan perawatan sarana dan prasarana. Penghitungan dana rutin yang diperlukan seorang peserta didik per tahun di sekolah digunakan analisis unit cost.

Nilai unit cost merupakan nilai satuan biaya yang dikeluarkan untuk memberikan pelayanan kepada seorang peserta didik per tahun dalam suatu jenjang pendidikan. Unit cost memberikan gambaran tentang besarnya dana yang dikeluarkan dan tingkat pelayanan yang diberikan. Perhitungan unit cost per peserta didik menurut Fattah ${ }^{4}$ adalah membagi jumlah dana yang tersedia dalam program anggaran dengan jumlah kredit yang diambil peserta didik per tahun dari program tersebut. Biaya program pengajaran per jam menurut Thomas (1971); dan Correa (1989) ditentukan oleh gaji guru dan tenaga administrasi, dana ruang; dana perlengkapan dan alat; serta dana bahan pelajaran.

Pembayaran gaji setiap pegawai ditentukan berdasarkan pangkat, jabatan, pendidikan, dan masa kerja yang diterima oleh seorang pegawai

4 Nanang Fattah, Ekonomi dan Pembiayaan Pendidikan, (Bandung: Remaja Rosdakarya, 2002), hlm. 26. 
minimal besarnya dapat memenuhi biaya hidup. Biaya hidup merujuk pada daya beli dari penghasilan yang diterima untuk memenuhi kebutuhan keluarga.

Dana ruang, menurut Thomas (1974:44) mencakup unsur-unsur sebagai berikut.

The first is the interest on unpaid debt; the second is the economic cost of the equity; the third is depreciation the annual decrease in value due to the anging of the building. Fourth is the overhead associated with spaceheat, light, and power. Fifth the cost of maintenance.

Kutipan tersebut menunjukkan bahwa dana ruang belajar yang digunakan seorang peserta didik per tahun secara garis besar dihitung dari dana penyusutan, dan overhead, dana perawatan, yang berlaku pada tahun tersebut. Dana perlengkapan dan alat pelajaran, menghitung dana perlengkapan dan alat pelajaran menurut Thomas didasarkan atas harga barang dan besarnya penyusunan per tahun. Besarnya dana perlengkapan dan alat pelajaran per tahun diperhitungkan satiap tahun anggaran yang berlaku.

2. Dana Masyarakat dan Dana Pribadi

Dana masyarakat (social cost) adalah dana yang dikeluarkan oleh masyarakat secara langsung dan tidak langsung, baik berupa uang, sekolah, uang buku, maupun dana lainnya. Dana tidak langsung yang dikeluarkan masyarakat seperti pajak dan restribusi.Di dalam social cost termasuk private cost, yaitu dana yang berasal dari rumah tangga termasuk kesempatan yang hilang. Private cost adalah dana langsung yang dikeluarkan dalam bentuk uang sekolah, uang kuliah, pembelian buku, dan dana hidup setiap peserta didik. Sementara dana tidak langsung merupakan income forgone setelah dikenai pajak.

3. Monetary and Non Monetary Cost

Monetary cost diartikan sebagai dana langsung dan tidak langsung yang dibayar oleh masyarakat dan individu, sedangkan non monetary cost ialah kesempatan yang hilang karena digunakan untuk membaca buku dan 
kegiatan belajar. Fattah ${ }^{5}$ mengemukakan bahwa di dalam menentukan dana satuan pendidikan terdapat dua pendekatan, yaitu pendekatan makro dan pendekatan mikro. Pendekatan makro didasarkan perhitungan pada keseluruhan jumlah pengeluaran pendidikan yang diterima dari berbagai sumber dana kemudian dibagi jumlah peserta didik. Pendekatan mikro didasarkan perhitungan dana alokasi pengeluaran per komponen pendidikan yang digunakan peserta didik.

\section{Pengelolaan Dana di Sekolah}

Ada beberapa faktor dalam manajemen pembiayaan pendidikan sebagaimana dikemukakan oleh Gaffar, ${ }^{6}$ yaitu sistem manajemen pembiayaan harus diikuti oleh pengelolaan keuangan, pengelolaannya tergantung apakah sistem itu cukup efisien atau tidak. Pada pemerintahan sistem terpusat, sistem pendanaan sangat sentralistis.Dalam arti pedoman anggaran yang sudah ada diatur secara sentral. Dengan sistem ini maka pengelolaan dan tidak mudah untuk dipahami.

Pendidikan memerlukan sejumlah investasi dari anggaran pemerintah dan dana masyarakat. Agar investasi di bidang pendidikan mencapai sasaran yang diharapkan diperlukan pengelolaan yang efektif dan efisisen. Kegiatan mengatur penerimaan, pengalokasian, dan mempertanggungjawabkan keuangan untuk menunjang pelaksanaan program pengajaran merupakan manajemen keuangan. Tugas pengelolaan keuangan dapat dibagi tiga fase, yaitufinancial planning, implementation, and evaluation.

Jones ${ }^{7}$ mengemukakan "financialplanning is called budgeting", merupakan kegiatan mengoordinasi semua sumber daya yang tersedia untuk mencapai sasaran yang diinginkan secara sistematis tanpa terjadi akibat efek sampingan yang merugikan. Pelaksanaan anggaran ialah kegiatan berdasarkan rencana yang telah dibuat dan kemungkinan terjadi penyesuaian bila diperlukan. Evaluation merupakaan proses evaluasi terhadap pencapaian sasaran.

$5 \quad$ Nanang Fattah, ibid., hlm. 26.

6 M, F Gaffar. (Perencanaan Pendidikan: Teori dan Metodologi, (Jakarta: P2LPTK, 1991: 10), hlm.10

7 Jones, School Finance: Technique and Social Policy, (London: Collier Macmillan Pub., 1985), hlm. 73. 
Komponen utama manajemen keuangan meliputi, (1) prosedur anggaran, (2) prosedur akuntansi keuangan; (3) pembelajaran. pergudangan, dan prosedur pendistribusian; (4) prosedur investasi; dan (5) prosedur pemeriksaan. Bertolak dari pengertian manajemen keuangan, tahapan (fungsi), dan komponen manajemen keuangan, maka proses manajemen keuangan perlu ada strategi pengelolaan.

\section{Strategi Sekolah dalam Pengelolaan Dana}

Sekolah merupakan suatu sistem, yang memiliki serangkaian komponen saling terkait, dan membutuhkan masukan dari lingkungan untuk mentransferkan serta mengeluarkan hasil. Kebutuhan akan masukan dan keluaran merupakan realitas dari ketergantungan sekolah terhadap lingkungan. Masukan terhadap sistem sekolah mencakup perangkat lunak dan perangkat keras, selaras dengan perkembangan yang terjadinya pada lingkungan. $\mathrm{Hal}$ tersebut memberikan konsekuensi terhadap transformasi dalam sistem sesuai dengan tuntutan keluaran.

Strategi pada hakikatnya merupakan cara berpikir manusia yang sistematis, yang akhir-akhir ini telah berkembang menjadi suatu landasan konseptual manajemen. Primozic (1991:163) mengidentifikasikan cara berpikir manusia, yakni "secara mekanik, intuisi, dan strategik". Cara berpikir tersebut, salah satunya yang kreatif dan dinamis selaras dengan perkembangan yang terjadi dalam kondisi tertentu.

Agustinus (1996:49) mengungkapkan bahwa karakteristik masalah strategi menyangkut orientasi ke masa depan, berhubungan dengan unit-unit kegiatan yang kompleks, perhatian manajemen puncak, pengaruh jangka panjang, dan alokasi sumber-sumber daya. Sehubungan dengan pendapat tersebut, berpikir strategis berkenaan dengan banyak pilihan sebagai alternatif pemecahan masalah.

Pemecahan masalah memerlukan seperangkat kemampuan analisis yang tepat dan cermat untuk memerkecil tingkat kesalahan yang timbul di masa depan. Rowe (1990) mengungkapkan tiga langkah utama pendekatan strategis dalam konteks manajemen, yaitu (1) strategic planning sebagai dokumen formal, (2) strategic management sebagai upaya untuk mengelola 
proses perubahan, dan (3) strategic thinking, sebagai kerangka dasar untuk merumuskan tujuan dan hasil yang dicapai ssecara berkesinambungan.

Strategic planning mengacu kepada keterkaitan antara tekanan internal yang datang dari dalam dan kebutuhan eksternal yang datang dari luar. Disini strategi mengandung unsur analisis kebutuhan, proyeksi, peramalan, pertimbangan ekonomis, dan financial, serta analisis terhadaap rencana jangka panjang dan rencana operasional dalam bentuk tindakan yang lebih rinci.

Kerangka manajemen strategik seperti dikemukakan Rowe $^{8}$ mencakup strategic planning, organizational structure, strategic control, and resources requirement.Strategic management merupakan pengelolaan terhadap keempat gugus komponen tersebut. Keempat gugus tersebut aktivitas kuncinya bertumpu pada strategic planning, sebab pada fase ini dilakukan analisis terhadap tantangan dan peluang eksternal, serta kekuatan dan kelemahan internal organisasi. Strategic management berfungsi mengarahkan operasi internal organisasi berupa alokasi sumber daya manusia, sarana fisik dan keuangan, untuk mewujudkan interaksi optimal dengan lingkungan sekitarnya.

Dalam kaitannya dengan strategi sekolah dalam menggali dana pendidikan, secara administratif strategi tersebut sangat tepat, karena berkaitan dengan bagaimana seorang pengelola sekolah melakukan upaya-upaya pengelolaan sumber daya, jenis sumber dana yang terdapat di dalam lingkungan sekolah. Strategi tersebut dapat direalisasikan melalui penyelenggara berbagai kegiatan sebagai berikut.

1) Melakukan analisis internal dan eksternal sekolah berkenaan dengan potensi sumber-sumber dana yang ada.

2) Mengidentifikasi dan memperkirakan sumber-sumber dana yang dapat digali.

3) Menetapkan sumber-sumber dana yang jelas dapat ditarik sebagai sumber perolehan seperti:

a) Musyawarah dengan orangtua peserta didik baru, pada awal tahun ajaran;

8 Rowe, Strategic Management, A Methodological Approach, (New York an Co: Addison - Wesley Publishing Company, 1990), hlm. 87. 
b) Musyawarah dengan dewan guru untuk mengembangkan koperasi sekolah;

c) Menyelenggarakan kegiatan olahraga dan kesenian peserta didik untuk mengumpulkan dana dengan memanfaatkan fasilitas sekolah.

\section{Perencanaan Pengelolaan Dana}

Perencanaan dalam manajemen keuangan (financial planning) ialah kegiatan merencanakan sumber dana untuk menunjang kegiatan pendidikan dan tercapainya tujuan sekolah. Perencanaan ini juga biasa disebut penganggaran (budgeting).Perencanaan menghimpun sejumlah sumber daya yang diarahkan untuk mencapai suatu tujuan "Budgeting brings fiscal resources demanded in planning and programming into sharper focus" (Knezevich, 1989:64). Anggaran atau budget merupakan alat penjabaran suatu rencana ke dalam bentuk dana untuk setiap komponen kegiatan. Dalam hal ini Richard Cordon (1976:125) mengemukakan pendekatan dalam menyusun anggaran pendidikan dalam dua pendekatan yang umum digunakan yaitu pendekatan tradisional dan Planning Programming Budgeting System(PPBS).

The Traditional Approach Stages: (1) As certain teacher needs in the areas of supplies, book, etc; (2) Determine the merits of teacher budget requests on the basis of perceived need; (3) Estimate the cost categories of need, e.g. instruction supplies, books, etc. PPBS Stages: (1) Asseses educational needs; (2) Define educational objectives and criteria and methods to be used in evaluating the objectives; (3) Determine programs and cost-estimate the resource needed to carry out programs; (5) Organize the budget arround program areas and objectives.

Ada dua bagian dalam penganggaran yaitu perkiraan tentang pendapatan dan pengeluaran. Prakiraan dan penyajian pendapatan harus dapat dipertanggung-jawabkan sehingga pendapatan itu dapat direalisasikan secara realistis.

Dalam kaitannya dengan pengelolaan dana pendidikan tingkat sekolah, sejalan dengan napas desentralisasi; Lipham (1985) mengemukakan tiga 
cara pandang, yaitu 1) Comparative Approach; penganggaran yang dilakukan dengan membandingkan besarnya penerimaan dan pengeluaran untuk setiap mata anggaran untuk setiap tahun; 2) The Planning Programming Budgeting Evaluation System (PPBES), penganggaran yang berorientasi pada rencana dan sasaran program secara khusus dan umum. Pendekatan ini analisis dana pelaksanaan, serta penilaian PPBES didasarkan atas zero-based budgeting; 3) Functional Approach: penganggaran dalam bentuk gabungan antara unsur PPBES dengan Comparative Approach.

\section{Prosedur Penyusunan Anggaran}

Prosedur perencanaan anggaran pendidikan pada umumnya dilakukan secara sederhana dan administrator dapat melaporkan secara sederhana pula. Perencanaan anggaran tersebut biasanya menggunakan format dari Rencana Anggaran Pendapatan dan Belanja Sekolah (RAPBS), yaitu (1) Sumber pendapatan terdiri dari UYHD, DPP, OPF dan BP3, dan lain-lain; (2) Pengeluaran untuk kegiatan belajar mengajar, pengadaan dan pemeliharaan sarana prasarana, bahan-bahan, dan alat pelajaran, honorarium dan kesejahteraan.

Lipham (1985) mengungkapkan empat fase kegiatan pokok penyusunan anggaran sebagai berikut.

1) Perencanaan anggaran merupakan kegiatan mengidentifikasi tujuan, menentukan prioritas, menjabarkan tujuan ke dalam penampilan operasional yang dapat diukur, menganalisis alternatif pencapaian tujuan dengan analisis cost-efectiveness, membuat rekomendasi alternatif pendekatan untuk mencapai sasaran.

2) Mempersiapkan anggaran, antara lain menyesuaikan kegiatan dengan mekanisme anggaran yang berlaku, bentuknya, distribusi, dan sasaran program pengajaran perlu dirumuskan dengan jelas. Melakukan inventarisasi kelengkapan peralatan, dan bahan-bahan yang telah tersedia.

3) Mengelola pelaksanaan anggaran, antara lain mempersiapkan pembukaan, melakukan pembelanjaan dan membuat transaksi, membuat perhitungan, mengawasi pelaksanaan sesuai dengan 
prosedur kerja yang berlaku, serta membuat laporan dan pertanggung-jawaban keuangan.

4) Menilai pelaksanaan anggaran, antara lain menilai pelaksanaan proses belajar-mengajar, menilai bagaimana pencapaian sasaran program, serta membuat rekomendasi untuk perbaikan anggaran yang akan datang.

Penyusunan anggaran memerlukan data yang akurat dan lengkap sehingga semua perencanaan kebutuhan untuk masa datang dapat diantisipasi dalam rancangan anggaran. Beberapa faktor yang turut mempengaruhi anggaran dana pendidikan di sekolah antara lain: laju pertumbuhan peserta didik, inflasi, pengembangan program, dan perbaikan serta peningkatan pendekatan belajar mengajar.

Mengenai perencanaan dan pembiayaan pendidikan Morphet (1975) mengajukan beberapa saran sebagai berikut.

1) Perencanaan pendidikan harus dapat mengganti beberapa peraturan dan prosedur yang tidak efektif sesuai dengan perkembangan kebutuhan pendidikan.

2) Merevisi peraturan dan input lain yang relevan, dengan merancang pengembangan sistem secara efektif.

3) Memonitor dan menilai keluaran pendidikan secara terus-menerus dan berkesinambungan sebagai bahan perencanaan tahap berikutnya.

Kutipan tersebut menunjukkan bahwa pengelolaan dana pendidikan tingkat sekolah dalam konteks otonomi daerah dapat diimplementasikan secara efektifdan berjalan efektifapabila didukung oleh beberapa sumber yang esensial, seperti: a) sumber daya manusia yang kompeten dan mempunyai wawasan luas serta tepat waktu dinamika sosial masyarakat; b) tersedianya informasi yang akurat dan tepat waktu untuk menunjang pembuatan keputusan; c) menggunakan manajemen dan teknologi yang tepat dalam perencanaan; d) tersedianya dana yang memadai untuk menunjang pelaksanaan. 


\section{Penyusunan Pendapatan dan Pengeluaran Anggaran Belanja Sekolah}

Penyusunan pendapatan dan pengeluaran anggaran belanja sekolah di lingkungan Departemen Pendidikan menganut pola paduan antara pengaturan pemerintah pusat dan sekolah. Artinya, ada beberapa anggaran yang telah ditetapkan oleh peraturan pemerintah yang intinya pihak sekolah tidak dapat mengubah dari petunjuk penggunaan atau pengeluarannya, dan sekolah hanya sebagai pelaksana pengguna dalam tingkat mikro kelembagaan. Dengan demikian, pola pengelolaan anggaran belanja sekolah, terbatas pada mengelola pada tingkat operasional.

Dalam hal ini. sekolah tidak mempunyai kebijakan pengelolaan secara operasional. Salah satu kebijakan tingkat sekolah adalah adanya pencarian tambahan dana dari partisipasi masyarakat.Sselanjutnya, cara pengelolaannya dipadukan sesuai tatanan yang lazim sesuai dengan peraturan yang berlaku. Namun demikian, sesuai dengan semangat otonomi daerah maka sekolah memiliki kewenangan dan keleluasaan yang cukup lebar dalam pengelolaan dana untuk mencapai efektivitas pencapaian tujuan sekolah.

Dalam pembuatan anggaran belanja sekolah yang sangat bertanggung jawab sebagai pelaksana adalah kepala sekolah. Kepala sekolah harus mampu mengembangkan sejumlah dimensi perbuatan administratif. Kemampuan untuk menerjemahkan program pendidikan ke dalam ekuivalensi keuangan merupakan hal penting dalam penyusunan anggaran belanja. Pembuatan anggaran belanja bukan pekerjaan rutin atau mekanis, melibatkan pertimbangan tentang maksud-maksud dasar dari pendidikan dan program. Dari perspektif tersebut pembuatan anggaran belanja dapat membuka jalan bagi pengembangan dan penjelasan konsep-konsep tentang tujuan-tujuan pendidikan yang diinginkan, dan merancang cara-cara bagi pencapaiannya.

Pengelolaan dana pendidikan tingkat sekolah dalam konteks otonomi daerah dilaksanakan oleh kepala sekolah dibantu para wakilnya yang ditetapkan oleh kebijakan sekolah, serta dewan sekolah di bawah pengawasan pemerintah. 


\section{Prosedur Pengaturan}

Dalam garis besarnya pengaturan dana pendidikan di sekolah meliputi penerimaan, penggunaan, dan pertanggungjawaban (auditing).

\section{a. Penerimaan Keuangan Sekolah}

Penerimaan keuangan sekolah dari sumber-sumber dana perlu dilakukan berdasarkan prosedur pengelolaan yang selaras dengan ketetapan yang disepakati, baik berupa konsep teoretis maupun peraturan pemerintah. Banyak pendekatan yang digunakan dalam pengelolaan dana pendidikan di sekolah, terutama berkaitan dengan penerimaan keuangan.Namun dalam penyelenggaraannya ada beberapa karakteristik yang identik.

Berdasarkan buku pedoman rencana, program dan penganggaran (Depdiknas, 2000) sumber dana pendidikan meliputi anggaran rutin (DIK); anggaran pembangunan (DIP); dana penunjang pendidikan (DPP); Dana BP3; donatur; dan lain-lain yang dianggap sah oleh semua pihak terkait.

Pendanaan pendidikan pada dasarnya bersumber dari pemerintah, orangtua, dan masyarakat. Di samping itu, dapat pula digali sumbersumber yang mungkin dari pihak masyarakat dalam bentuk saling menguntungkan.

\section{b. Penggunaan Keuangan Sekolah}

Dana yang diperoleh dari berbagai sumber perlu digunakan secara efektif dan efisien. Artinya, setiap perolehan dana dalam pengeluarannya harus didasarkan pada kebutuhan-kebutuhan yang telah disesuaikan dengan perencanaan pembiayaan di sekolah.

Pengeluaran sekolah berhubungan dengan pembayaran keuangan sekolah untuk pembelian beberapa sumber atau input dari proses sekolah seperti tenaga administrasi, guru, bahan-bahan, perlengkapan, dan fasilitas. Ongkos menggambarkan seluruh sumber yang digunakan dalam proses sekolah, apakah digambarkan dalam anggaran sekolah dan pengeluaran atau tidak. Ongkos dari sumber sekolah termasuk nilai setiap input yang digunakan, sekalipun sekolah menyumbangkan atau tidak terlihat secara akurat. 
Dalam SKB Mendiknas dan Menkeu No.0585/K/1997 dan No.590/kmk.03/03/1987, tanggal 24-9-1987 tentang peraturan SPP dan DPP meliputi: pelaksanaan pelajaran, pengadaan prasarana/sarana, pemeliharaan sarana dan prasarana, kesejahteraan pegawai, kegiatan belajar, penyelenggaraan EBTA/EBTANAS dan pengiriman/penulisan STTB/NEM, perjalanan dinas supervisi, pengelolaan pelaksanaan pendidikan, dan pendataan.

Sesuai dengan semangat otonomi pendidikan, maka kepala sekolah berwewenang penuh untuk mengatur masalah pendanaan pendidikan di sekolahnya. Meskipun demikian, ia harus tetap memperhatikan perangkat peraturan yang ada dan selaras dengan rincian pengeluaran.

\section{c. Pertanggungjawaban Keuangan Sekolah}

Pertanggungjawaban atau evaluasi keuangan sekolah dilakukan terhadap apa yang telah dicapai sesuai dengan tujuan yang telah ditetapkan. Menurut Cormark (1970) "auditing is verification, auditing is determining that what is intended is what is being performed and, further that what is being performed is appropriate for the task." Auditing merupakan pembuktian dan penentuan bahwa apa yang dimaksud sesuai dengan yang dilaksanakan, sedang apa yang dilaksanakan sesuai dengan tugas. Proses ini menyangkut pertanggungjawaban penerimaan, penyimpanan, dan pembayaran atau penyerahan dana kepada pihak-pihak yang berhak secara proporsional.

\section{E. Kesimpulan}

Kebijakan pemberian otonomi daerah dan desentralisasi yang luas, nyata, dan bertanggung jawab kepada daerah merupakan langkah strategis dalam dua hal. Pertama, otonomi daerah dan desentralisasi merupakan jawaban atas permasalahan lokal bangsa berupa ancaman disintegrasi bangsa, kemiskinan, ketidakmerataan pembangunan, rendahnya kualitas hidup masyarakat, dan masalah pembangunan sumber daya manusia. Kedua, otonomi daerah dan desentralisasi merupakan langkah strategis bangsa Indonesia untuk menyongsong era globalisasi ekonomi dengan memperkuat basis perekonomian daerah. 
Kesadaran tentang pentingnya pendidikan yang bermutu dapat memberikan harapan dan kemungkinan yang lebih baik di masa mendatang, hal ini telah mendorong berbagai upaya dan perhatian seluruh lapisan masyarakat untuk bisa meningkatkan kualitas pendidikan. Sekolah sebagai institusi (lembaga) pendidikan, merupakan wadah tempat proses pendidikan dilakukan, memiliki sistem yang kompleks dan dinamis. Dalam kegiatannya, sekolah adalah tempat yang bukan hanya sekedar tempat berkumpul guru dan murid, melainkan berada dalam satu tatanan sistem yang rumit dan saling berkaitan, oleh karena itu sekolah dipandang sebagai suatu organisasi yang membutuhkan pengelolaan, termasuk didalamnya pengelolaan dana.

Pendidikan merupakan proses interaksi sosial yang melibatkan sumber daya manusia, sarana, dan dana dalam merealisasikan tujuannya. Ketiga sumber daya tersebut perlu dikelola secara efektif dan efisien untuk mencapai tingkat produktivitas pendidikan yang tinggi, baik secara kuantitas maupun kualitas.

Peningkatan produktivitas pendidikan memerlukan pengelolaan yang baik dari tingkat nasional sampai tingkat operasional, karena manajemen pendidikan merupakan faktor kunci untuk menunjang keberhasilan pelaksanaan program pendidikan. Dalam hal ini untuk meningkatkan produktivitas pendidikan dapat dilakukan melalui perbaikan sistem pengelolaan dana pendidikan di sekolah. Hal ini penting terutama dalam kaitannya dengan otonomi daerah dan desentralisasi pendidikan yang sedang bergulir.

Pendidikan memiliki nilai monetary (direct and indirect cost) sehingga tidak bebas dari dana. Dalam hal ini, dana yang diinvestasikan ke dalam sistem pendidikan diharapkan memberikan kembalian secara individual dan sosial. Dana langsung (direct cost) digunakan untuk menunjang proses pembelajaran, sedang dana tidak langsung (indirect cost) merupakan biaya hidup seorang peserta didik, dan kebutuhan lain yang menyebabkan ia dapat hadir di sekolah. Pengelolaan dana pendidikan tingkat sekolah yang efektif dan efisien dapat mengantisipasi upaya peningkatan mutu pendidikan di masa depan. Implikasi lebih lanjut dari kajian tentang biaya pendidikan dapat dijadikan landasan dalam menganalisis pengelolaan dana pendidikan di sekolah. 


\section{DAFTAR PUSTAKA}

Anderson, L and Douglas M, W. 1982. Education and Development. Toronto: Lexington Books D.C. Heath and Company Lexington, Massachusetts.

Becker, Gary, S. 1993. Human Capital: A Theoretical and Empirical Analysis with Special Reference to Education (Third Edition). USA: The University of Chicago Press

Cohn, Elchanan. 1979. The Economic of Education: An Introduction. Massachussets: Ballinger Pub. Company.

Djatmiko, Y, H. 2005. Bahan Perkuliahan Teori dan Proses Kebijakan Pendidikan.Bandung: PPs Upi.

Engkoswara. 1987. Dasar-dasar Administrasi Pendidikan. Jakarta: Dirjen Dikti Depdikbud.

Fiske, Edward, B. 1996. Decentralilization of Education: Politics and Concensus. London: Collier Macmillan Pub.

Fattah, Nanang. 2000. Ekonomi dan Pembiayaan Pendidikan. Bandung: Remaja Rosdakarya.

Gaffar, M, F. 1989. Perencanaan Pendidikan: Teori dan Metodologi. Jakarta: P2LPTK

Hansen, Don, R and Mowen, M, M. 2000. Manajemen Biaya: Akuntansi dan Pengendalian.Jakarta: Penerbit Salemba Empat.

Iaditris, Demetrius. 1994. Social Policy "Institusional Context of Social Development and Human Services". New York, London: Collier Macmillan

Jones. 1985. School Finance: Technique and Social Policy.London: Collier Macmillan Pub.

Mardiasmo. 2002. Otonomi \& Manajemen Keuangan Daerah. Yogyakarta: Andi.

Mattulada. 1990. Desentralisasi Pendidikan Dalam Pelaksanaan Manajemen Pembangunan. Jakarta: Pustaka Sinar Harapan. 
Nurhadi, M, A. 1999. Pokok-pokok Pikiran Mengenai Pengelolaan Bidang Pendidikan dan Kebudayaan Dalam Rangka Pelaksanaan UndangUndang RI No. 22. Jakarta: Makalah Seminar.

Pidarta, M. 1988. Manajemen Pendidikan Indonesia. Jakarta: Bumi Aksara.

Rae, Duncan, Mac, and James A.Wilde. 1985. Policy Analysis For Public Decisions. New York: University Press of America.

Rowe 1989. Strategic Management, A Methodological Approach. New York an Co: Addison - Wesley Publishing Company.

Rusmana, Maman. 2000. Formasi: Jurnal Kajian Manajemen Pendidikan. Bandung: PPs UPI.

Sallies, E. 1994. Total Quality Management in Education. London: Kogan Page Limited

Sergoivanni, Thomas, J. 1987. Educational Governance and Administration. New Jersey: Prentice Hall Inc.

Undang-Undang No. 20 tahun 2003 Tentang Sistem Pendidikan Nasional.

Vaizey, John. 1962. The Economic of Education.London: Feber Limited. 